\title{
FINANCIAL TECHNOLOGY AND IT'S IMPACT ON MSMES IN CHOOSING BANK CREDIT SERVICES IN JAMBI
}

\author{
Eka Julianti Efris Saputri 1), Fitri Chairunnisa ${ }^{2)}$ \\ ${ }^{1)}$ Universitas Adiwangsa Jambi, Jambi, Indonesian \\ ${ }^{2)}$ Universitas Jambi, Jambi, Indonesian \\ Corresponding author: ekajuliantiefrissaputri@gmail.com; fchair85@gmail.com
}

\begin{abstract}
Fintech supports the implementation of electronic applications, one of which is access to financial inclusion; this is evident from the increasing financial inclusion in Indonesia, one of which is in Jambi City. Until 2018, the development of bank credit debit trays in Indonesia continued to increase. With the presence of fintech companies in Indonesia, several SMEs who were met admitted to applying for credit and using bank credit services, namely applications launched by Fintech companies. This type of research is descriptive qualitative. The data collection method in this research is by distributing questionnaires and conducting interviews with correspondents. By using logistic regression, the purpose of this study is to determine the factors that influence SMEs in choosing bank credit services in Jambi City with the presence of financial technology. The results are only a few factors that influence SMEs in choosing bank credit services in Jambi.
\end{abstract}

Keywords: Bank, Bank Services, Bank Credit, Financial Technology, Fintech, SMEs

\section{Introduction}

After passing the MEA, Indonesia is now entering a digital era called The Industrial Revolution 4.0 era. The Industrial Revolution 4.0 network era is not just a trend, but it has become a basic necessity of society from children to adults.

The results of a national survey of Internet user penetration in Indonesia conducted by Poling Indonesia in collaboration with APJII in 2018 revealed that the percentage of Internet users in Indonesia increased by $10.12 \%$ compared to 2017 , namely 143.26 million people from the total population of Indonesia amounted to 262 million people for 2017 and amounted to 171.17 million Internet users out of the total population of Indonesia of 264.16 million people for 2018 (Asosiasi Penyelenggara Jasa Internet Indonesia, 2019).

Technological developments are very influential in industrial revolution 4.0, which gave birth to the latest innovations based on technology that will contribute to the emergence of new sectors and new companies and the loss of professions related to the low-skilled workforce. The birth of the latest innovations based on technology is unstoppable, except in the financial sector, which is often called Financial Technology (Fintech). In Japan, the number of mobile phone users is increasing rapidly. However, the adoption of Fintech is slow and banks offering Fintech services need to convince their customers of the added value benefits of Fintech (Stewart, H., \& Jurjens, J, 2018).

Fintech supports the implementation of electronic applications, one of which is access to financial inclusion; this is evident from the increasing financial illusion in Indonesia, one of which is in the city of Jambi. Similarly, MSMEs are the backbone of the economy in Indonesia, with a GDP contribution rate of $59 \%$ and a labor absorption rate of $97 \%$ of the total labor force in Indonesia. Only 59\% of MSMEs have financial access to banks, and only $26 \%$ use credit loans from banks to develop their businesses (Kurniasari, F., \& Endarto, E. A, 2018). Research results of the Indonesian Banking Development Institute (2015) stated that MSME Credit from 2011 to 2014 increased by an average of 13.63\% per year. However, about 60\% $70 \%$ of all MSME sector actors still do not have access to financing through banking. Therefore, the MSME sector is a huge market potential for banks to channel financing. Until 2018, the development of credit debit tray in banks in Indonesia continues to increase to Rp. 1,086,082.3 billion (Bank Indonesia, 2019). Therefore, this research will examine factors that influence MSMEs in choosing bank credit services in Jambi with Financial Technology.

Governor of Indonesian Bank Agus D.W. Martowardojo at the launching of Bank Indonesia Fintech Office (BI-FTO) held in Jakarta, November 14, 2016, revealed that the global financial crisis in 2008 had shaken public confidence in the financial system. In these conditions, financial technology (Fintech) companies were born as an alternative solution to meet the community's needs for financial services. Fintech offers the latest options for consumers in conducting fund intermediation, remittance, payment, and investment activities (Anonim, 2017). Furthermore, the Governor of BI said that it supports the development of the digital economy in Indonesia, including small and medium-sized businesses.

Several studies have been conducted related to the reasons for the public in choosing bank services, including products and facilities offered by banks such as easy access to transactions (Saputri, E.J.E., Rahayu, S, Wahyudi, I, 2018) which Fintech is very influential in this regard. Muchlis proves that SWOT analysis on fintech banking financing is known that the development of development products will be better, 
where Fintech will always keep up with existing developments and be easy to adjust, following the development of customer needs (Muchlis, 2018).

The government provides regulation so that MSMEs get loans to develop their businesses by utilizing peer-to-peer lending (FINTECH) in Indonesia (BI Fintech Office, 2017). Fintech is expected to boost the growth of the digital economy while bringing people closer to financial inclusion. One of the critical factors in increasing public trust is the existence of reasonable regulatory arrangements to protect the public interest on the one hand, but still pay attention to the business development space for the industry, on the other hand, until now, there is no regulation of the Indonesian government on Fintech there is only a Regulation from OJK RI No.77/POJK.01/2016 on information technology-based lending services.

The business world in Jambi Province is still dominated by Micro Small Enterprises (MSEs). From the results of SE2016, the number of businesses reached more than 311 thousand businesses, or 98.90 percent of the total non-agricultural businesses in Jambi Province. This business can also absorb a workforce of more than 718 thousand people or about $85.99 \%$. With a population of almost $17 \%$ of the total population of Jambi Province, Jambi city is still the concentration of MSEs (Central Statistics Agency of Jambi Province, 2019). The number of Jambi City MSEs per year 2017 reached more than 19 percent (Badan Pusat Statistik Provinsi Jambi, 2019) with the development of Credit Debit tray in banks amounting to Rp. 15,711.2 Billion (Bank Indonesia, 2019).

MSME lending in the fourth quarter of 2018 was recorded at $37.64 \%$ of the total lending in Jambi Province, down from $38.10 \%$ in the previous quarter. More specifically, the share of credit to micro, small and medium enterprises in the fourth quarter of 2018 to total lending in Jamb Province, imposing $13.46 \%$ in micro-enterprises, and $13.14 \%$ in small businesses, while $11.04 \%$ share of medium business loans.

This research intended to examine the factors that influence MSMEs in choosing bank credit services in Jambi with financial technology.

\section{Research Method}

The population in this study is the perpetrators of Usana Micro Small Medium. The selection of samples tested in this study used the Nonprobability Sampling technique (Sugiyono, 2012). Data collection method in this study by disseminating questionnaires and conducting direct interviews with respondents. By using the Slovin formula, 88 samples will be tested in this study.

Independent variables in this research are Interest Rate, Products, level of trust, ease of transaction, terms, guarantees, contract process, services. Variable dependent in this research is the decision of MSMEs in choosing credit services with financial technology.

This study's data analysis techniques are logistic regression by using the wald test and overall test fit model. Before performing the Logistic Regression Test, the collected data will be done a validity and reliability test to ensure that no errors in the data or data can be said to be reliable and valid. If the data to be tested is reabel and valid, then it will be done normality test with Kolmogorov-Smirnov test, which can then be done testing related to the statistical model. This research will be tested in a model below:

$$
Y=\beta_{0}+\beta_{1} X_{1}+\beta_{2} X_{2}+\beta_{3} X_{3}+\beta_{4} X_{4}+\beta_{5} X_{5}+\beta_{6} X_{6}+\beta_{7} X_{7}+\beta_{8} X_{8}+e
$$

\section{Result and Discussion}

The validity and reliability tests on the data collected from 88 respondents can be concluded that each indicator in the variable is valid and reliable. Suppose the results of the questionnaire data test are said to be valid and reliable. In that case, the normality test will then be carried out before the logistic regression test is carried out.

\section{Normality Test}

The normality test of data was conducted with Kolmogorov-Smirnov nonparametric statistic test, which can be seen in table 1 .

Table 1. One - Sample Kolmogorov-Smirnov Test

\begin{tabular}{llr}
\hline & & Unstandardized Residual \\
\hline $\mathrm{N}$ & & 88 \\
\hline Normal Parameters, & Mean & .0000000 \\
\cline { 2 - 3 } & Std. Deviation & .482176345 \\
\hline Most Extreme Differences & Absolute & .114 \\
\cline { 2 - 3 } & Positive & .114 \\
\cline { 2 - 3 } & Negative & -.94 \\
\hline Test Statistic & & .129 \\
\hline Asymp. Sig. (2-tailed) & & $.153^{\mathrm{c}}$ \\
\hline
\end{tabular}

The Kolmogorov-Smirnov test results showed that the statistical test value of 0.129 with the asymp value of Sig (2-tailed) $0.153>0,05$. These results say that the residual variables are normally distributed. 


\section{Logistic Regression}

This test aims to determine how independent variables affect dependent variables that can be seen in table 2. Accepted hypotheses or variables can be said to affect if the significance value is greater than the significance level of $0.05(5 \%)$.

Table 2. Output Logistic Regression Wald Test Variables in the Equation

\begin{tabular}{|c|c|c|c|c|c|c|c|}
\hline & & $\mathrm{B}$ & S.E. & Wald & Df & Sig. & $\operatorname{Exp}(B)$ \\
\hline \multirow{9}{*}{$\begin{array}{l}\text { Step } \\
1^{\mathrm{a}}\end{array}$} & Interest Rate & -.216 & .188 & 1.323 & 1 & .250 & .805 \\
\hline & Products & .630 & .234 & 7.248 & 1 & .007 & 1.878 \\
\hline & Level of Trust & .092 & .309 & .088 & 1 & .767 & 1.096 \\
\hline & Ease of Transaction & -.206 & .378 & .297 & 1 & .586 & .814 \\
\hline & terms & -.271 & .178 & 1.040 & 1 & .009 & .625 \\
\hline & Guarantees & .234 & .346 & .456 & 1 & .499 & 1.264 \\
\hline & Contract process & .360 & .348 & 1.071 & 1 & .301 & 1.434 \\
\hline & Services & -.522 & .203 & 6.633 & 1 & .010 & .593 \\
\hline & Constant & .246 & 1.091 & .051 & 1 & .822 & 1.279 \\
\hline
\end{tabular}

The logistic regression equation of the output logistic regression in Table 2 can be written as follows:

$\mathrm{Y}=0,246+-0,216 \mathrm{X} 1+0,630 \mathrm{X} 2+0,092 \mathrm{X} 3+-0,206 \mathrm{X} 4+-0,271 \mathrm{X} 5+0,234 \mathrm{X} 6+0,360 \mathrm{X} 7+-0,522 \mathrm{X} 8$

Table 2 shows that the independent variables, namely products, terms, and services, are said to have an effect on the dependent variable with a significance of the value of $0.007,0.009$, and 0.010 , which means that in choosing MSME bank credit services, they still see the types of products offered, the terms for applying for credit, and bank services. While the variables of interest rates, levels of trust, ease of transactions, collateral, and contract processes do not significantly affect MSMEs in choosing bank services.

\section{Coefficient of Determination (Nagelkerke R Square)}

The coefficient of determination aims to find out how much variability of dependent variables can be explained by the independent variable shown in table 3

Table 3. Coefficient of Determination Model Summary

\begin{tabular}{|c|c|c|c|}
\hline Step & $\begin{array}{c}-2 \text { Log } \\
\text { likelihood }\end{array}$ & $\begin{array}{c}\text { Cox \& Snell R } \\
\text { Square }\end{array}$ & $\begin{array}{c}\text { Nagelkerke R } \\
\text { Square }\end{array}$ \\
\hline 1 & $102.964^{\mathrm{a}}$ & .294 & .359 \\
\hline
\end{tabular}

The value of the coefficient of determination in the logistic regression model is shown by the Nagelkerke $\mathrm{R}$ Square value. Nagelkerke R Square's value is 0.359 , which means the variability of dependent variables explained by independent variables is $35.9 \%$, while the remaining $64.1 \%$ is explained by other variables outside the research model.

\section{Overall model fit.}

Overall models are used to see if indicators in independent variables are feasible in research that will affect dependent variables.

Table 4. Values -2 Log-likelihood with Coefficient Constanta Iteration History, b,c

\begin{tabular}{lrrr}
\hline & & \multicolumn{2}{c}{ Coefficients } \\
Iteration & -2 Log likelihood & Constant \\
\hline Step 0 & 1 & 121.994 & .000 \\
\hline
\end{tabular}

Table 5. Value -2 Log-likelihood with Constanta

\begin{tabular}{cccc}
\hline \multicolumn{2}{c}{ Iteration } & -2 Log likelihood & Constant \\
\hline \multirow{3}{*}{ Step 1 } & 1 & 103.753 & .030 \\
\cline { 2 - 4 } & 2 & 102.975 & .221 \\
\cline { 2 - 4 } & 3 & 102.964 & .245 \\
\cline { 2 - 4 } & 4 & 102.964 & .246 \\
\hline
\end{tabular}

Table 4 shows the value of -2 Log Likelihood is 121,994, compared with the Chi-Square value at a significance level of 0.05 with $\mathrm{df}$ of $\mathrm{N}-1$ with $\mathrm{N}$ is the number of samples, meaning $88-1=87$. From the 
Chi-Square table, the value is 109.77331 . So, the value of -2 Log Likelihood is more critical than the chisquare value. The $-2 \log$ Likelihood value is 121.994 greater than the Chi-Square value of 109.77331, which means indicators in independent variables are influential or worthy of being a factor in determining MSMEs in choosing bank credit services.

However, there is a decrease of -2 Log-Likelihood, which can be seen in table 5 from 121,994 to 102,964, with a difference of 19,030 .

The test results of 88 sample in this study, known the length of business that has been carried out by respondents dominated in respondents who have run their business at a vulnerable time of 5 to 10 years by $43 \%$. Wald test shows that product factors, terms, and services provided influence MSMEs in choosing bank credit services in Jambi. These are in line with the statement (He, D., Leckow, R., Haksar, V., Griffoli, T. M., Jenkinson, N., Khiaonarong, T., et al., 2017) how Fintech can provide solutions that respond to consumers' needs for trust, security, privacy, better service, and changing the competitive landscape. The statement contradicts the statistics produced that trust does not affect MSMEs in choosing bank credit services in Jambi.

In addition to disseminating questionnaires, researchers also conducted interviews with MSME businesses in Jambi; in fact, some MSME actors in choosing credit services are still influenced by consumer confidence factors because they know one of the company's employees that offers products and data security provided by consumers. Stewart, H., \& Jurjens, J (2018) stated that data security and interface meetings when conducting transactions affect customer trust, as there is a strong relationship between quality and trust. However, the new findings found at the time of this research are that some businesses are just starting their businesses have made online loans offered by Fintech with peer to peer lending services as well as pay later services both offered by banks and companies other than banks where many businesses do not know the impact of online credit used whether safe or not. Despite the existence of fintech services for credit services, this will not make the credit products provided by banks will be extinct.

Nurcahya, Y.A., \& Dewi, R.P. (2019) stated that financial technology is an innovation that is considered to increase the market share of MSMEs as a step in addressing problems related to capital financing, the building of financial statements, payments, and marketing, as well as financial transactions and other financial literacy. There are three critical roles of MSMEs, namely: (1) Means of avoiding people from poverty, (2) Means to level the economy of tiny people, (3) Providing foreign exchange income for the state. However, several risks must be faced by investors, namely the credibility of $p 2 p$ lending service providers, there are loan payments that are delayed, and there is a risk of default. Therefore, investors should have a strategy to manage these risks with wise action.

In implementing Fintech, there is a need that arises before MSME actors finally decide to apply Fintech. The decision was supported by offers from service providers, as well as information from fellow businesses. After applying, there is resistance to costs arising from the application of fintech services. Businesses need to make price adjustments to their products. In the end, businesses maintain services that benefit their businesses (Luckandi, 2018).

Fintech has played an increasingly significant role in shaping the financial and banking landscape. Technology allows banks and fintech lenders to serve small businesses and consumers without physical investment (Jagtiani \& Lemieux, 2018); it is also evident that many fintech products are offered to MSMEs, both offered by banks and non-banks.

Egger (2002) states that usability, attractiveness, and perception are essential determinants of the trust model. This is in line with the results of interviews with respondents who, some respondents stated dare to take credit services because they are interested in the products offered, and some respondents as businesses dare to do credit offered by non-banks because of the benefits they get. Ease of transaction, non-graceful contract pross and more accessible terms than doing credit in the bank make businesses prefer credit services provided by companies other than banks such as pay later from Ovo and shoppee, akulaku from bukalapak, kredivo, and others. Actors need to admit that although there is a credit limit allowed for each account owner, the credit services they provide help the continuity of their business by purchasing primary needs, especially MSMEs in the food industry.

The diversity of financial products offered makes it easier for MSMEs to choose according to their business portfolio. While the administrative terms are not rigid to be an advantage where it does not focus on the need to complete the complexity of the terms documents so that it can make it easier for MSMEs to use financial technology facilities, and the ease of access to technology-based services can provide opportunities for MSMEs to be able to access services anytime and anywhere according to their needs.

\section{Conclusion}

From several factors tested, namely interest rate factor, products offered, level of trust, ease of transaction, terms, guarantees provided, contract process, services provided, only 3 factors that influence MSMEs in choosing bank credit services in Jambi are the products offered, terms, and services provided. The diversity of financial products offered makes it easier for MSMEs to choose according to their business portfolio. While the administrative terms are not rigid becomes an advantage where it does not focus on the need to complete the complexity of the terms documents so that it can make it easier for MSMEs to use 
financial technology facilities and the ease of access to technology-based services can provide opportunities for MSMEs to be able to access services anytime and anywhere according to their needs.

In addition to direct interviews with MSME businesses in Jambi, some businesses are categorized as lower-middle-class use loans offered by fintech services such as direct credit loans from pay later applications from Ovo and shoppee, akulaku by bukalapak, kredivo, and others. However, the credit weakness given to each account owner is limited. Usually, businesses take advantage of loans or purchases of goods credits in the application to purchase basic business needs (such as buying beverage powder, UHT milk, equipment, and business equipment in the food and beverage business). Despite the existence of fintech services for credit services, this will not make the credit products provided by banks will be extinct. People still think that if doing credit with the services provided by Fintech is afraid in the future if something happens, they do not know who should ask who because of the lack of knowledge related to loans provided by fintech companies other than banks and the lack of businesses that use credit services under fintech companies other than banks. This is misleading among MSME activists and becomes an obligation for banking services to provide more understanding about this fintech facility in the future.

\section{References}

Anonim. (2017). Ramai-Ramai Garap Fintech. Probank.

Arner, D. W., Barberis, J., \& Buckley, R. P. (2015). The Evolution Of Fintech: A New Post-Crisis Paradigm? The HKU Scholars Hub. University of Hongkong.

Asosiasi Penyelenggara Jasa Internet Indonesia. (2019). Hasil Survei Nasional Penetrasi Pengguna Internet Tahun 2018. Ver:S20190518.

Badan Pusat Statistik Jambi. (2019). Potensi Peningkatan Kinerja Usaha Mikro Kecil Provinsi Jambi. Provinsi Jambi: Katalog: 9102059.15.

Bank Indonesia. (2016, November 14). Launching Bank Indonesia Fintech Office.

Bank Indonesia. (2019). In Kajian Ekonomi dan Keuangan Regional Provinsi Jambi. Provinsi Jambi: Kantor Perwakilan Bank Indonesia Provinsi Jambi.

Egger, F. (2002). Consumer Trust in E-Commerce: From Psychology to Interaction Design. The Hague, NL: Kluwer law International.

Ghazali, I. (2011). Aplikasi Analisis Multivariate Dengan Program IBM SPSS 19 Jilid 5. Semarang: BP UNDIP.

He, D., Leckow, R., Haksar, V., Griffoli, T. M., Jenkinson, N., Kashima, M., . . Tourpe, H. (2017). Fintech and Financial Services: Initial Considerations. IMF Staff Team.

Jagtiani, J., \& Lemieux, C. (2018). Do Fintech Lenders Penetrate Areas That Are Underserved by Traditional Banks? Federal Reserve Bank of Philadelphia.

Kurniasari, F., \& Endarto, E. A. (2018). Pengaruh Teknologi Digital Terhadap Keputusan Pelanggan Dalam Memilih TekFin Pinjaman di Indonesia. Jurnal Manajemen Bisnis Vol.13.

Luckandi, D. (2018). Analisis Transaksi Pembayaran Menggunakan Fintech Pada UMKM di Indonesia: Pendekatan Adaptive Structuration Theory. Thesis Universitas Islam Indonesia.

Maisur, Arfan, M., \& Shabri, M. (2015). Pengaruh Prinsip Bagi Hasil, Tingkat Pendapatan, Religiusitas, Dan Kualitas Pelayanan Terhadap Keputusan Menabung Nasabah Pada Bank Syariah Di Banda Aceh. Jurnal Magister Akuntansi Pascasarjana Universitas Syiah Kuala.

Muchlis, R. (2018). Analisis SWOT Financial Technology (Fintech) Pembiayaan Perbankan Syariah Di Indonesia (Studi Kasus 4 Bank Syariah Di Kota Medan). At-Tawassuth Vol. III No.2.

Nazori. (2017). Politik Hukum Perkreditan/Pembiayaan Dan Jaminan Atas Fasilitas Yang Diberikan Kepada UMKM Studi Komperatif antara Indonesia dan Malaysia. Disertasi UNJA.

Nurcahya, Y. A., \& Dewi, R. P. (2019). Analisis Pengaruh Perkembangan Fintech dan E-Commerce Terhadap Perekonomian Masyarakat. Fintech dan E-Commerce untuk Mendorong Pertumbuhan UMKM dan Industri Kreatif. Magelang: Fakultas Ekonomi Universitas Tidar.

Nurmantyo, B., Ipada, F., Miranti, I., Gunanto, K., Oeliestina, Marini, P., . . . Sumarni. (2019). In Potensi Peningkatan Kinerja Usaha Mikro Kecil Provinsi Jambi "Analisis Hasil SE2016 Lanjutan". Jambi Province: Badan Pusat Statistik Provinsi Jambi.

Ramanova, I., \& Kudinska, M. (2017). Banking And Fintech: A Challange Or Opportunity. Emerald Insight.

Saputri, E. J., Rahayu, S., \& Wahyudi, I. (2018). Pengaruh Prinsip Bagi Hasil dan Bunga, Reputasi Bank dan Asimetri Informasi Terhadap Keputusan Nasabah Dalam Memilih Jasa Perbankan: Bank Syariah dan Bank Konvensional di Kota Jambi. Jurnal Akuntansi dan Keuangan UNJA Vol 3 No 3.

Setiadi. (2008). Perilaku Konsumen Konsep dan Implikasinya untuk Strategi dan Penelitian Pemasaran. Prenada Media Group.

Stewart, H., \& Jurjens, J. (2018). Data Security and Consumer trust in Fintech Innovation In Germany. Emerald Insight.

Sugiyono. (2012). Metodologi Penelitian Bisnis. Bandung: ALFABETA.

Thakor, A. V. (2019). Fintech and Banking: What Do We Know? Journal Of Financial Intermediation.

Undang-Undang Republik Indonesia Nomor 20. (2008). Tentang Usaha Mikro, Kecil, dan Menengah. Jakarta. 
Undang-Undang Republik Indonesia Nomor 21. (2008). Tentang Perbankan. Jakarta. 